Jurnal Kompetitif : Media Informasi Ekonomi Pembangunan, Manajemen dan Akuntansi

Vol. 6 No. 2, September 2020

\title{
PENGARUH PEMBERIAN KREDIT MODAL KERJA TERHADAP PENDAPATAN PEDAGANG KECIL ( Studi Kasus Pada PD. BPR NTB LOBAR CABANG GUNUNGSARI TAHUN 2018 )
}

\author{
Suhardi Ansor ${ }^{1)}$ \\ Baiq Dewi Lita Andiana ${ }^{2}$ \\ Universitas Islam Al-Azhar ${ }^{1)}$ \& 2) \\ 1)Email: adixenxor@gmail.com \\ ${ }^{2)}$ Email: dewilita123@gmail.com
}

\begin{abstract}
This study aims to determine whether there is an influence on the granting of working capital loans to the income of small traders in PD. BPR NTB West Lombok Gunungsari Branch. This type of research is associative research which aims to determine the relationship between two or more variables. The data used in this study are primary data and secondary data. Primary data is data taken directly from the field, while secondary data is data obtained through intermediary media such as books, records, evidence and archives published or not. Data analysis in this study uses validity test, reliability test, normality test, linearity test, simple linear regression test, correlation test and coefficient of determination. Based on the results of the tests that have been carried out, it can be concluded that the granting of working capital loans has a significant influence on the income level of small traders.
\end{abstract}

\section{PENDAHULUAN}

\section{Latar Belakang}

Pertumbuhan ekonomi sebagai hasil dari pembangunan ekonomi harus dapat meningkatkan kesejahteraan rakyat secara merata. Penyebaran yang merata dari hasil pembangunan akan dapat diwujudkan dalam melalui kebijakan perdagangan yang mendorong dan membantu pengusaha kecil dalam sektor perdagangan. Dalam memajukan kegiatan perekonomian perlu melibatkan banyak pihak antara lain BUMN, swasta, koperasi, maupun pelaku ekonomi berskala kecil. Keterbatasan modal akan membatasi ruang gerak pedagang kecil dalam menjalankan serta meningkatkan usahanya. Dengan kepemilikan modal yang sangat terbatas serta sangat sulitnya mendapatkan modal dari luar membuat semakin sulitnya para pedagang kecil mengembangkan usahanya. Usaha 
Jurnal Kompetitif : Media Informasi Ekonomi Pembangunan, Manajemen dan Akuntansi Vol. 6 No. 2, September 2020

pemerintah dalam mengembangkan usaha pedagang kecil yaitu dengan memberikan bantuan dan bimbingan teknis serta pelatihan keterampilan serta pemasaran. Sedangkan bantuan ekonomi yaitu dengan pemberian bantuan kredit. Oleh karena itu pemerintah, dalam hal ini yaitu Pemda Lombok Barat memberikan kemudahan untuk mendapatkan modal melalui PD. BPR NTB Lombok Barat sebagai salah satu badan perkreditan yang dimiliki oleh pemerintah yang berada di tingkat kecamatan yang akan memberikan kemudahan para pedagang kecil untuk mendapatkan modal melalui kredit yang mudah, murah serta suku bunga yang rendah yang dihadirkan di tengah- tengah kehidupan para pelaku ekonomi berskala kecil guna meningkatkan dan mengembangkan usahanya serta yang paling diharapkan adalah meningkatkan pendapatan pedagang kecil agar kesejahteraan pedagang kecil lebih terjamin.

Kecamatan Gunungsari masih terdapat beberapa pedagang kecil yang kekurangan modal dan masih membutuhkan tambahan modal untuk mengembangkan usahanya. Dan inilah fungsi di dirikannya PD. BPR NTB Lombok Barat oleh pemerintah daerah untuk membantu pedagang kecil dalam mengatasi masalah permodalan. Kredit yang diberikan diharapkan sesuai dengan kemauan dan kemampuan pedagang kecil dalam mengunakan kreditnya secara selektif guna mencapai tujuan yang diinginkan serta tidak membebani pedagang kecil . Keberadaan PD. BPR NTB Lombok Barat Kecamatan Gunungsari diharapkan akan menjadi pemecahan masalah dan membantu pedagang kecil dalam mendapatkan tambahan yang mereka butuhkan modal melalui kredit yang terjangkau dan prosedur yang sederhana. Dengan tambahan modal yang diberikan, usaha pedagang kecil akan semakin meningkat dan berkembang dengan ketersediaan barang yang bertambah, dan diharapkan pendapatan pedagang kecil akan semakin meningkat.

\section{TINJAUAN PUSTAKA}

\section{Kajian Teoritis}

\section{Konsep Pendapatan}

Pendapatan adalah jumlah penghasilan yang diterima oleh penduduk atas prestasi kerjanya selama satu periode tertentu, baik harian, mingguan, bulanan ataupun tahunan. Beberapa klasifikasi pendapatan antara lain: 
Jurnal Kompetitif : Media Informasi Ekonomi Pembangunan, Manajemen dan Akuntansi Vol. 6 No. 2, September 2020

a. Pendapatan pribadi, yaitu; semua jenis pendapatan yang diperoleh tanpa memberikan suatu kegiatan apapun yang diterima penduduk suatu Negara.

b. Pendapatan disposibel, yaitu; pendapatan pribadi dikurangi pajak yang harus dibayarkan oleh para penerima pendapatan, sisa pendapatan yang siap dibelanjakan inilah yang dinamakan pendapatan disposibel.

c. Pendapatan nasional, yaitu; nilai seluruh barang-barang jadi dan jasa-jasa yang diproduksikan oleh suatu Negara dalam satu tahun. ${ }^{1}$

Sedangkan Pendapatan disposibel adalah suatu jenis penghasilan yang diperoleh seseorang yang siap untuk dibelanjakan atau dikonsumsikan. Besarnya pendapatan disposibel yaitu pendapatan yang diterima dikurangi dengan pajak langsung (pajak perseorangan) seperti pajak penghasilan. Masalah pendapatan tidak hanya dilihat dari jumlahnya saja, tetapi bagaimana distribusi pendapatan yang diterima oleh masyaraka ${ }^{2}$. Pendapatan yang diperoleh oleh pengusaha dapat dibagi menjadi dua yaitu : Pendapatan bersih dan pendapatan kotor. Pendapatan bersih adalah pendapatan yang diperoleh dari seluruh penghasilan dikurangi dengan seluruh biaya dan pendapatan kotor adalah pendapatan yang diperoleh dari penjualan total kepada para pembeli selama periode yang bersangkutan ${ }^{3}$.

\section{Pedagang Kecil}

Pengungkapan definisi secara jelas dan baku tentang PKL memang belum ada, mengingat penelitian pada sektor ini masih sedikit dilakukan.Adapun definisi dari PKL adalah pedagang kecil yaitu orang yang dengan modal yang relatif sedikit melaksanakan aktifitas produksi dalam arti luas (produksi barang, menjual barang dan menyelenggarakan jasa) untuk memenuhi kebutuhan kelompok konsumen tertentu dalam masyarakat usaha yang mana dilaksanakan ditempat-tempat yang dianggap strategis dan ekonomis dalam suasana lingkungan yang informal ${ }^{4}$. Menurut PD. BPR NTB Lombok Barat Cabang

\footnotetext{
${ }^{1}$ Sukirno,Sadono, 2006, Ekonomi Pembangunan, Jakarta,Kencana

2 Sobri. 1987. Pengantar Ekonomi Makro. Edisi Revisi Cetakan Kedua. Yogyakarta: BPFE. UI.

${ }^{3}$ Jusup Al.Haryono. (1997). Dasar-Dasar Akuntansi. Sekolah Tinggi Ilmu Ekonomi YKPN- Yogyakarta,

${ }^{4}$ Winardi., 1986, Asas-asas Manajemen, Bandung: Alumni.
} 
Jurnal Kompetitif : Media Informasi Ekonomi Pembangunan, Manajemen dan Akuntansi Vol. 6 No. 2, September 2020

Gunungsari yang dikategorikan pedagang kecil adalah para pedagang yang mempunyai modal awal dibawah Rp.25.000.000,-5 .

\section{Bank Perkreditan Rakyat (BPR)}

Bank Perkreditan Rakyat (BPR) merupakan lembaga keuangan bank yang menerima simpanan hanya dalam bentuk deposito berjangka, tabungan, dan/atau bentuk lainnya yang dipersamakan dan menyalurkan dana sebagai usaha BPR. Menurut pasal 13 UU Perbankan No. 10 tahun 1998, Bank Perkreditan Rakyat mempunyai suatu kegiatan usaha yaitu sebagai berikut : Bank perkreditan rakyat (BPR) merupakan bank yang melaksanakan kegiatan usaha secara konvensional atau berdasarkan prinsip syariah, yang dalam kegiatannya tidak memberikan jasa dalam lalu lintas pembayaran. Fungsi utama BPR adalah memberikan bantuan kredit baik berupa kredit investasi maupun kredit eksploitasi dalam skala kecil dengan jaminan kepada rakyat yang berada di daerah ${ }^{6}$. Kegiatan BPR untuk mendukung fungsinya tersebut antara lain memberikan pelayanan kepada masyarakat untuk menerima tabungan mereka dalam bentuk deposito berjangka, tabungan, dan/atau bentuk lainnya yang dipersamakan dengan itu; memberikan kredit; menyediakan pembiayaan bagi nasabah berdasarkan prinsip bagi hasil sesuai dengan ketentuan yang ditetapkan dalam peraturan pemerintah; dan menempatkan dananya dalam bentuk Sertifikat Bank Indonesia (SBI), deposito berjangka, sertifikat deposito, dan atau pada bank lain.

\section{Kredit}

Pengertian kredit yang lebih mapan untuk kegiatan perbankan di Indonesia telah dirumuskan dalam Undang - Undang Pokok Perbankan No. 7 Tahun 1992 yang menyatakan bahwa kriteria adalah penyediaan uang / tagihan yang dapat dipersamakan dengan itu berdasarkan persetujuan / kesepakatan pinjam meminjam antara pihak bank

\footnotetext{
${ }^{5}$ Brosur Bank Perkreditan Rakyat, 2010,"Model Bisnis Bank Perkreditan Rakyat"

${ }^{6}$ Republik Indonesia.Undang-undang Perbankan Pasal 13 No.10 Tahun 1998 Tugas dan Kegiatan Bank Perkreditan Rakyat
} 
Jurnal Kompetitif : Media Informasi Ekonomi Pembangunan, Manajemen dan Akuntansi Vol. 6 No. 2, September 2020

dengan pihak lain yang mewajibkan pihak peminjam untuk melaksanakan dengan jumlah bunga sebagai imbalan. Untuk mendapatkan kredit harus melalui prosedur yang telah ditentukan oleh bank / lembaga keuangan (SOP Kredit BPR). Agar kegiatan pelaksanaan perkreditan dapat berjalan dengan sehat dan layak, dikenal dengan $6 \mathrm{C}$ yaitu : (1) Character (kepribadian / Watak) dari pemohon kredit; (2) Capacity (kemampuan) adalah kesanggupan pemohon untuk melunasi kewajibannya; (3) Capital (modal) merupakan modal yang dimiliki calon debitur pada saat mereka mengajukan permohonan kredit pada bank; (4) Collateral (jaminan) adalah barang - barang yang diserahkan pada bank oleh peminjan atau debitur sebagai jaminan atas kredit yang diberikan; (5) Condition of Economic (kondisi ekonomi) merupakan situasi dan kondisi, sosial, ekonomi, budaya dan lainnya yang mempengaruhi keadaan perekonomian pada suatu saat maupun untuk satu kurun waktu tertentu yang kemungkinannya akan dapat mempengaruhi kelancaran usaha dari perusahaan yang memperoleh kredit; dan (6) Constrain (batasan atau hambatan) adalah hambatan yang tidak memungkinkan sesorang melakukan usaha di suatu tempat.

\section{Modal}

Modal adalah sekumpulan uang atau barang yang digunakan sebagai dasar untuk melaksanakan suatu pekerjaan ${ }^{7}$. Modal merupakan hal yang sangat vital dalam sebuah bisnis atau perusahaan. Tanpa modal bisnis tidak dapat berjalan sebagaimana mestinya. Mulai dari bisnis yang besar maupun bisnis yang kecil pun membutuhkan modal untuk menjalankan bisnisnya.

Berdasarkan sumbernya modal dibedakan menjadi dua, yaitu modal internal yang didapatkan dari perusahaan itu sendiri biasanya dari hasil penjualan, dan modal eksternal adalah modal yang berasal dari luar perusahaan atau dana yang diperoleh dari para kreditur ataupun dari pemegang saham yang dapat ambil bagian dalam perusahaan. Dilihat dari fungsinya, modal digolongkan menjadi modal perseorangan dan modal sosial. Sedangkan berdasarkan penggunaannya, modal digunakan untuk tujuan sebagai investasi dan modal kerja.

\footnotetext{
${ }^{7}$ Riyanto, Bambang. 2013. Dasar-Dasar Pembelanjaan Perusahaan. Edisi Keempat. BPFE-Yogyakarta. Yogyakarta.
} 
Jurnal Kompetitif : Media Informasi Ekonomi Pembangunan, Manajemen dan Akuntansi Vol. 6 No. 2, September 2020

\section{Hubungan Pemberian kredit dengan peningkatan pendapatan}

Pengembangan usaha dilakukan untuk meningkatkan pendapatan atau penghasilan dengan harapan dapat untuk mencapai kesejahteraan. Dalam pengembangan usaha ini kendala modal akan menjadi masalah yang sangat fundamental, kebijakan dari debitur untuk mengajukan pinjaman kredit merupakan langkah awal untuk memulai pengembangan usahanya. Dana dari pinjaman kredit ini akan sangat membantu bagi mereka untuk mengembangkan usaha, dalam pengembangan usaha yang dijalankan tentu akan membutuhkan modal yang tidak sedikit, maka dengan melakukan pinjaman mereka akan dapat mempeoleh dana untuk melakukan ekspansi. Pendapatan bersih para pedagang adalah selisish antara pendapatan kotor dengan pengeluaran total para pedagang sehingga dapat di ukur dengan melihat laba yang diperleh oleh para pedagang ${ }^{8}$.

\section{Tinjauan Empiris}

Menurut hasil penelitian dari Desna Putri Pamulasari (2013) degan judul "Pengaruh Pemberian Kredit Modal Kerja terhadap Peningkatan Pendapatan Usaha Mikro Kecil dan Menengah pada Kopersari Wijaya di Kelurahan Wirun Kecamatan Mojolaban”. Secara simultan terdapat pengaruh yang signifikan atara pemberian kredit terhadap peningkatan pendapatan UMKM dengan dimana pemberian kredit pengaruh secara signifikan terhadap peningkatan pendapatan pedagang kecil dan menengah pada Koperasi Kartika Wijaya di Kelurahan wirun Kecamatan Mojolaban memiliki pengaruh yang signifikan dengan hasil uji koefisien determinasi (R2) sebesar 0,696 menunjukan bahwa besarnya pengaruh pemberian kredit terhadap peningkatan pendapatan Pedagang kecil adalah sebesar 69,6\% sedangkan sisanya 30,4\% dipengaruhi oleh variabel diluar penelitian ${ }^{9}$. Penelitian serupa juga dilakukan oleh Linda Kumalasari (2013) yang berjudul "Pengaruh Pengambilan Kredit di Koperasi Jasa Keuangan Syariah (KJKS) terhadap pendapatan pedagang kecil di pasar Tanjung Kabupaten Jember tahun 2012/2013”, dimana hasil penelitannya menunjukkan secara simultan terdapat pengaruh yang signifikan antara pengambilan kredit di Koperasi

${ }^{8}$ Gilarso T. (2004).Pengantar Ilmu Ekonomi Makro. Yogyakarta : Karnisus.

${ }_{9}$ Desna Putri Pamulasari (2013) degan judul "Pengaruh Pemberian Kredit Modal Kerja terhadap Peningkatan Pendapatan Usaha Mikro Kecil dan Menengah pada Kopersari Wijaya di Kelurahan Wirun Kecamatan Mojolaban”. 
Jurnal Kompetitif : Media Informasi Ekonomi Pembangunan, Manajemen dan Akuntansi Vol. 6 No. 2, September 2020

Jasa Keuangan syariah terhadap pendapatan pedagang kecil di Pasar Tanjung Kabupaten Jember tahun 2012/2013 dengan hasil uji koefesien (R2) sebesar 0,708 menunjukan bahwa besarnya pengaruh pengambilan kredit di Kopersasi Jasa Keuangan Syariah terdadap pendapatan pedagang kecil di Pasar Tanjung Kabupaten Jember Tahun 2012/2013 adalah sebesar $70,8 \%$, sedangkan $29,2 \%$ sisanya dipengaruhi oleh variabel diluar penelitian ${ }^{10}$.

\section{Kerangka Konseptual}

\section{Kerangka Konseptual}

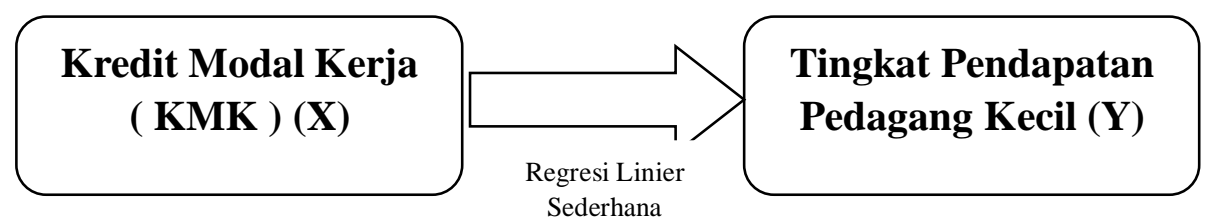

\section{Hipotesis}

Ho : Diduga tidak terdapat pengaruh pemberian kredit modal kerja terhadap peningkatan pendapatan pedagang kecil pada PD. BPR Lobar Cabang Gunungsari

Ha : Diduga terdapat pegaruh pemberian kredit modal kerja terhadap peningkatan pendapatan pedagang kecil pada PD. BPR Lobar Cabang Gunungsari

\section{METODE PENELITIAN}

Penelitian ini merupakan kuantitatif dengan pendekatan asosiatif, dimana penelitian ini bertujuan untuk mengetahui hubungan antara dua variabel atau lebih yaitu variabel kredit modal kerja $(\mathrm{X})$ dengan variabel pendapatan pedagang kecil $(\mathrm{Y})$, objek dalam penelitan ini adalah nasabah peminjam pada kantor PD. BPR NTB Lombok Barat Cabang Gunungsari tahun 2018. Teknik pengumpulan data dengan menyebarkan kuesioner tertutup mengenai pengaruh pembiayaan pedagang kecil terhadap pendapatan pedagang kecil sebelum dan sesuadah menerima pinjaman. Kuesioner ini menyajikan pertanyaan dan

${ }^{10}$ Linda Kumalasari (2013) yang berjudul "Pengaruh Pengambilan Kredit di Koperasi Jasa Keuangan Syariah (KJKS) terhadap pendapatan pedagang kecil di pasar Tanjung Kabupaten Jember tahun 2012/2013. 
Jurnal Kompetitif : Media Informasi Ekonomi Pembangunan, Manajemen dan Akuntansi Vol. 6 No. 2, September 2020

pilihan jawaban sehingga responden hanya dapat memberikan tanggapan terbatas pada pilihan yang diberikan. Adapun responden yang akan mengisi kuesioner adalah nasabah yang mata pencahariannya sebagai pedagang kecil di Desa Gunungsari. Selain kuesioner peneliti juga mengumpulkandokumentasi berupa data-data yang diterbitkan oleh PD. BPR NTB Lombok Barat yaitu pembiayaan pedagang kecil di wilayah Gunungsari.

Populasi merupakan keseluruhan objek atau subjek yang berada dalam satu wilayah dan memenuhi syarat-syarat tertentu dan berkaitan dengan maslah penelitian ${ }^{11}$ dimana populasi yang diteliti adalah semua nasabah aktif yang berprofesi sebagai pedagang kecil berjumlah 135 debitur yang dibiayai oleh PD. BPR NTB Lobar Cab. Gunungsari selama tahun 2018. Sebagian dari jumlah dan karakteristik yang dimiliki oleh populasi tersebut, ataupun bagian kecil dari anggota populasi yang diambil menurut prosedur tertentu yang mewakili populasi tersebut ${ }^{12}$ diperoleh jumlah sampel sebanyak 57 debitur yang dibiayai oleh pada PD. BPR NTB Lombok Barat Cabang Gunungsari pada tahun 2018. Teknik pengambilan sampel menggunakan cara Proportionate Stratified Random Sampling karena populasinya mempunyai anggota/unsur yang tidak homogen dan berstrata secara proporsional $^{13}$.

Tabel 1.1

Pembagian Sampel Penelitian

\begin{tabular}{|c|c|c|c|c|}
\hline \multirow{2}{*}{ Kredit yang diterima } & \multirow{2}{*}{ Populasi } & \multicolumn{2}{|c|}{ Sampel } & \multirow{2}{*}{\begin{tabular}{c} 
Proporsi \\
\cline { 3 - 4 }
\end{tabular}} \\
\cline { 3 - 4 } & & Rumus & Jumlah & $(\%)$ \\
\hline Rp.0,- s.d Rp.5.000.000,- & 33 & $57 / 135 \times 33$ & 14 & 22,44 \\
\hline >Rp.5.000.000,-s.d Rp.10.000.000,- & 31 & $57 / 135 \times 31$ & 13 & 22,96 \\
\hline$>$ Rp.10.000.000,-s.d Rp.15.000.000,- & 19 & $57 / 135 \times 19$ & 8 & 14,07 \\
\hline$>$ Rp.15.000.000,-s.d Rp.20.000.000,- & 9 & $57 / 135 \times 9$ & 4 & 6,666 \\
\hline$>$ Rp.20.000.000,-s.d Rp.25.000.000,- & 43 & $57 / 135 \times 43$ & 18 & 31,85 \\
\hline Total & $\mathbf{1 3 5}$ & & $\mathbf{5 7}$ & $\mathbf{1 0 0}$ \\
\hline
\end{tabular}

Sumber : Data diolah Lampiran 3.

\footnotetext{
${ }^{11}$ Setiawan,Santy. 2012. Statistika II.. Bandung: ANDI

12 Sugiyono. 2011. Statistika untuk Penelitian. Bandung: Alfabeta.

${ }^{13}$ Sugiyono. 2011. Statistika untuk Penelitian. Bandung: Alfabeta.
} 
Jurnal Kompetitif : Media Informasi Ekonomi Pembangunan, Manajemen dan Akuntansi Vol. 6 No. 2, September 2020

Jenis data yang dilakukan dalam penelitian ini adalah data kuantitatif. Dimana data jawaban nasabah yang diperoleh dari hasil kuesioner diolah guna menganalisis pengaruh pembiayaan pedagang kecil terhadap pendapatan usaha nasabah pada PD. BPR NTB Lobar Cabang Gunungsari. Sedangkan sumber data yang digunakan adalah data primer berupa data kuesioner yang dikumpulkan dari nasabah dan data sekunder dokumen yang dikeluarkan oleh PD. BPR NTB Lombok Barat Cabang Gunungsari.

Variabel yang digunakan dalam penelitian ini adalah Pembiayaan pedagang kecil sebagai variable bebas (X) dan variabel pendapatan usaha sebagai variable terikat (Y). Pembiayaan modal kerja yang dimaksud adalah kredit modal kerja yang diberikan kepada pedagang kecil merupakan program jangka pendek yang diberikan PD. BPR NTB Lombok Barat untuk usaha nasabah dengan memenuhi indikator pemenuhan kebutuhan, peningkatan kualitas, peningkatan produksi dan keperluan perdagangan. Sedangkan Pendapatan usaha merupakan sejumlah uang yang diperoleh dari hasil usaha setelah dikurangi biaya produksi dan pajak atau hasil kerja dari penjualan atau pelunasan hutang selama satu periode. Indikator yang digunakan adalah peningkatan pendapatan dan pelunasan hutang.

Untuk menganalisa pengaruh antara variabel-variabel yang ada peneliti menggunakan metode analisis antara lain:

1. Analisis Pendapatan

Pendapatan adalah selisih antara penerimaan dengan semua biaya yang dikeluarkan selama melakukan kegiatan usaha. Ada beberapa pengertian yang perlu diperhatikan dalam menganalisis pendapatan antara lain ${ }^{14}$ penerimaan, adalah jumlah produksi yang dihasilkan dalam suatu kegiatan usaha dikalikan dengan harga jual yang berlaku di pasar. Sedangkan pendapatan bersih adalah penerimaan kotor yang dikurangi dengan total biaya produksi atau penerimaan kotor di kurangi dengan biaya variabel dan biaya tetap. Biaya produksi adalah semua pngeluaran yang dinyatakan dengan uang yang diperlukan untuk menghasilkan produksi. Pendapatan kotor pedagang kecil didefinisikan sebagai nilai

\footnotetext{
${ }^{14}$ Soekartawi. 1994. Prinsip Dasar Ekonomi Pertanian: Teori dan Aplikasi. Rajawali Press. Jakarta.
} 
Jurnal Kompetitif : Media Informasi Ekonomi Pembangunan, Manajemen dan Akuntansi Vol. 6 No. 2, September 2020

penjualan dalam jangka waktu tertentu, baik yang dijual maupun tidak dijual. Jangka waktu pembukuan umumnya adalah satu tahun.

\section{Uji Validitas Instrumen}

Dalam penentuan layak atau tidak layaknya suatu item dalam kuesioner yang akan digunakan, biasanya digunakan uji signifikansi koefesien korelasi pada taraf signifikansi 0,05 artinya suatu item dianggap valid jika berkorelasi signifikan terhadap skor total ${ }^{15}$.

\section{Uji Reliabilitas}

Reliabilitas menunjuk pada tingkat keterandalan sesuatu. Realibilitas dalam penelitian ini menggunakan dengan metode Cronbach Alpha dan skala yang digunakan adalah skala likert. Skala likert digunakan untuk mengukur pendapat, sikap dan persepsi seseorang atau sekelompok orang tentang fenomena sosial.

\section{Uji Normalitas}

Untuk menguji data variabel $\mathrm{X}$ dan variabel $\mathrm{Y}$ pada persamaan regresi yang dihasilkan yaitu berdistribusi normal dan tidak normal. Dalam uji normalitas ini peneliti menggunakan teknik kolmogrov-smirnov yang menggunakan taraf signifikan > 5\% $(\mathrm{p}=0,05)$ pegujian ini menggunakan bantuan SPSS 20 for windows.

\section{Uji Linearitas}

Uji linearitas menggunakan compare means (tesof linierty), yang datanya diolah dengan SPSS 20 for windows. Penyajiannya menggunakan analisis tabel ANOVA, kriteria yang ditetapkan untuk menentukan kelinearitasan garis regresi adalah jika koefisien signifikasi lebih besar dari harga alpha yang ditentukan 5\% (0,05) maka dinyatakan bahwa garis regresi dinyatakan linear.

6. Uji Regresi Linier Sederhana

Uji Regresi Linier Sederhana adalah pengujian terhadap data yang mana terdiri dari dua variabel, yaitu satu variabel independen dan satu variabel dependen dimana variabel tersebut bersifat kausal (berpengaruh) ${ }^{16}$. Persamaan dari regresi linier sederhana adalah :

$$
\mathbf{Y}=\mathbf{a}+\mathbf{b X}+\mathbf{e}
$$

\footnotetext{
${ }^{15}$ Azwar, Saifuddin (1999) Metode Penelitian. Pustaka Pelajar Yogyakarta
} 
Jurnal Kompetitif : Media Informasi Ekonomi Pembangunan, Manajemen dan Akuntansi

Vol. 6 No. 2, September 2020

Dimana :

$\mathrm{Y}=$ Peningkatan pendapatan seteleh memperoleh kredit

$\mathrm{a}=$ Bilangan konstanta $\quad \mathrm{b}=$ Bilangan koefisien dari variabel $\mathrm{X}$

$\mathrm{X}=$ Pemberian kredit $\quad \mathrm{e}=$ Standar eror

7. Uji Korelasi ( Uji T )

Uji hipotesis menggunakan rumus korelasi product moment, dimana pengolahan datanya menggunakan SPSS 20 for windows. Tujuan dari analisis koefisien korelasi ini adalah untuk mengetahui seberapa kuat pengaruh dari variabel X (Pemberian kredit modal kerja) terhadap variabel Y (Pendapatan pedagang kecil).

8. Koefisien Determinasi ( $R$ Squre )

Analisis ini digunakan untuk melihat persentase (\%) dan mengetahui besarnya kontribusi pengaruh variabel X ( Pemberian kredit modal kerja) terhadap variabel Y ( Pendapatan pedagang kecil) dan analisis ini harus dihitung dengan rumus koefisien determinasi sebagai berikut :

$$
\mathrm{Kd}=\mathbf{r s}^{2} \times 100 \%
$$

Dimana :

Kd : Koefisien determinasi

rs : koefisien korelasi rank spearmen

\section{HASIL PENELITIAN DAN PEMBAHASAN}

\section{Hasil Penelitian}

\section{Profil Persuahaan PD. BPR NTB Lobar Cabang Gunungsari}

Sebagai badan usaha yang berorientasi pada dunia ekonomi kerakyatan, PD.BPR NTB Lombok Barat Cabang berdiri dengan semangat memberikan pelayanan yang terbaik 
Jurnal Kompetitif : Media Informasi Ekonomi Pembangunan, Manajemen dan Akuntansi Vol. 6 No. 2, September 2020

kepada masyarakat, terutama masyarakat yang membutuhkan layanan dana dan jasa keuangan yang lain serta dapat membantu pendapatan daerah. Produk-produk PD.BPR NTB Lobar Cabang Gunungsari sangat beragam, dari kredit sampai deposito dan tabungan. Produk kredit yang sesuai dengan kondisi nasabah, pilihan yang sangat pas memungkinkan para nasabah dengan mudah mendapatkan layanan yang terbaik. Ini merupakan upaya yang sangat membantu pengembangan serta perkembangan perekonomian masyarakat saat ini. PD. BPR NTB Lobar Cabang Gunungsari menjadi anggota dari Lembaga Penjamin Simpanan (LPS), hingga simpanan masyarakat mendapat jaminan sesuai dengan ketentuan yang berlaku. Sekaligus masyarakat memperoleh keuntungan yang lebih tinggi dibanding bank umum.

\section{Karakteristik Responden}

Responden yang berjenis kelamin laki-laki yaitu sebanyak 31 responden $(54,4 \%)$ dan sisanya adalah responden dengan jenis kelamin perempuan sebanyak 26 responden $(45,6 \%)$ dengan kata lain laki-laki yang menjadi debitur peminjam pada kantor PD.BPR NTB Lombok Barat Cabang Gunungsari dominan laki-laki karena mereka sebagian besar merupakan kepala rumah tangga yang menjalankan usahanya sebagai para pedagang. Dari sisi modal, modal pedagang kecil Rp.0 s/d Rp.5.000.000,- memperoleh rata-rata pendapatan bersih dari penjualan selama satu tahun Rp.117.360.000,-, modal >Rp.5.000.000,- s/d Rp.10.000.000,- = Rp.171.000.000,-, modal >Rp.10.000.000,- s/d Rp.15.000.00,- = Rp.289.800.000,-, modal >Rp.15.000.000,- s/d Rp.20.000.000,- = Rp.919.800.000,- dan modal pedagang kecil >Rp.20.000.000,- s/d Rp.25.000.000,- = Rp.432.000.000,- sedangkan pedagang kecil yang mempunyai modal ditas Rp.25.000.000,- tidak ada dalam penelitian ini. Pendapatan tertinggi pedagang kecil sebelum menerima kredit adalah pedagang yang mempunyai modal Rp.15.000.000,- s/d Rp.20.000.000,-. 
Jurnal Kompetitif : Media Informasi Ekonomi Pembangunan, Manajemen dan Akuntansi Vol. 6 No. 2, September 2020

\section{ANALISIS DATA}

\section{Analisis Pendapatan Bersih Pedagang Kecil Setelah Mendapat Kredit Modal Kerja}

Analisis pendapatan pendapatan kecil digunakan untuk mengetahui tingkat pendapatan yang diperoleh para pedagang sebelum dan sesudah menerima kredit modal kerja dari PD.BPR NTB Lobar Cabang Gunungsari. Perbandingan pendapatan pedagang kecil sebelum dan setelah menerima kredit modal kerja dari PD. BPR NTB lobar Cabang Gunungsari adalah pedagang yang mempunyai modal Rp.0 s/d Rp.5.000.000,- peningkatan rata-rata pendapatannya selama satu tahun sebesar Rp.12.600.000,- modal >Rp.5.000.000,s/d Rp.10.000.000,- = Rp.5.760.000,- Modal >Rp.10.000.000,- s/d Rp.15.000.000,- = Rp.3.960.000,- modal >Rp.15.000.000,- s/d Rp.20.000.000,- = Rp.27.360.000,- dan modal >Rp.20.000.000,- s/d Rp.25.000.000,- = Rp.27.000.000,-. Rata-rata pendapatan tertinggi pedagang setelah menerima kredit modal kerja adalah pedagang kecil yang mempunyai modal >Rp.15.000.000,- s/d Rp.20.000.000,- yaitu sebesar Rp.27.360.000,-

\section{Uji Validitas}

Teknik yang digunakan untuk uji validitas adal korelasi product moment dari person dengan tingkat kepercayaan 95\% $(\alpha=0,05)$ dilakukan dengan mengkorelasi skor masingmasing item dengan skor totalnya. Adapun hasil uji validitas dengan menggunakan aplikasi SPSS 20 for windows diperoleh hasil bahwa keseluruhan item variabel peneliti mempunyai $\mathrm{r}$ hitung $>$ dari $\mathrm{r}$ tabel dengan taraf signifikan 95\% $(\alpha=0,05)$ dan $\mathrm{n}=57$ diperoleh dari $\mathrm{r}$ tebel $=0,2162$, maka dapat diketahui $\mathrm{r}$ hasil tiap-tiap item $>$ dari 0,2162 sehingga dapat dikatakann bahwa keseluruhan item penelitian ini adalah valid untuk digunakan sebagai instrumen dalam penelitian ${ }^{17}$.

\footnotetext{
${ }^{17}$ Azwar, Saifuddin (1999) Metode Penelitian. Pustaka Pelajar Yogyakarta.
} 
Jurnal Kompetitif : Media Informasi Ekonomi Pembangunan, Manajemen dan Akuntansi Vol. 6 No. 2, September 2020

\section{Uji Reliabilitas}

Hasil uji reliabilitas dengan bantuan program SPSS 20 for windows dengan metode Cronbach Alpha diketahui bahwa nilai Cronbach Alpha $1>\mathrm{r}$ tabel dengan taraf signifaksi sebesar 0,05 maka dapat dikatakan bahwa item-item tersebut reliabel Saifudin Azwar (1999 dengan. Dengan taraf signifasi sebesar $0,05 \mathrm{n}=57$ nilai $\mathrm{r}$ tabel $=0,2162$ maka dapat kita simpulkan bahwa item-item tersebut reliable.

\section{Uji Normalitas}

Tabel 1.2

One-Sample Kolmogorov-Smirnov Test

\begin{tabular}{|ll|l|}
\hline & & Unstandardized Residual \\
\hline Normal Parameters ${ }^{a, b}$ & Mean & 57 \\
& Std. Deviation & $0 \mathrm{E}-7$ \\
& Absolute & 1,67336528 \\
Most Extreme Differences & Positive &, 139 \\
& Negative &, 118 \\
Kolmogorov-Smirnov $Z$ & &,- 139 \\
Asymp. Sig. (2-tailed) & & 1,051 \\
\hline
\end{tabular}

Sumber : Lampiran 7

Berdasarkan hasil uji normalitas pada data diatas dapat kita lihat hasil Asyimtotic sig $(2$-tiled $)=0,219$ lebih besar dari pada 0,05 maka dapat kita simpulkan bahwa distribusi data pada pemberian kredit terhadap pendapatan para pedagang kecil adalah normal.

\section{Uji Linearitas}

Tabel 1.3

ANOVA Table

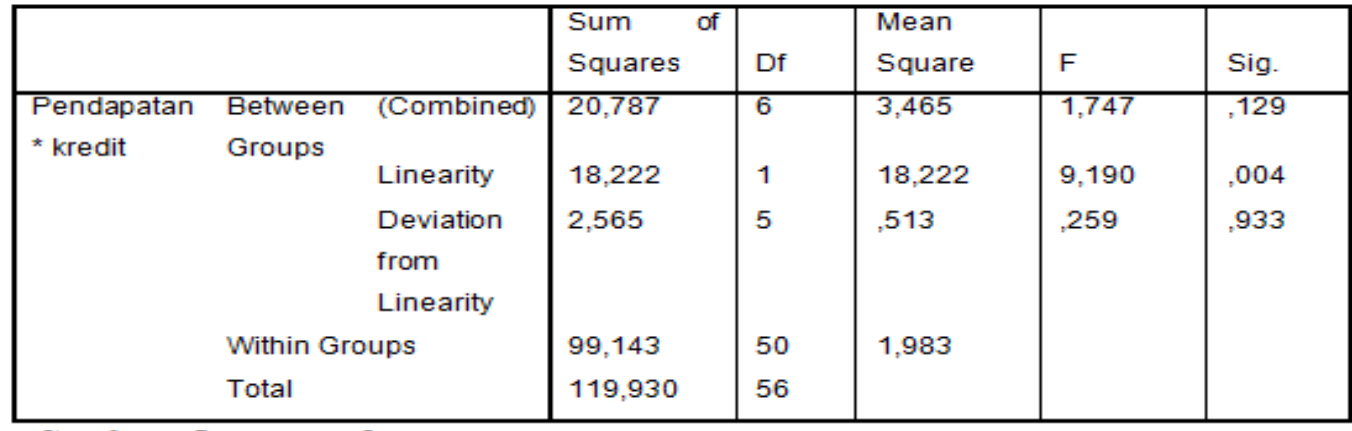

Sumber : Lampiran 8 
Jurnal Kompetitif : Media Informasi Ekonomi Pembangunan, Manajemen dan Akuntansi Vol. 6 No. 2, September 2020

Dari hasil pengujian diatas dapat dilihat hasil dari sig. $=0,933$ lebih besar dari 0,05 maka dapat kita simpulkan ada hubungan linear yang signifikan antara pemberian kredit modal kerja dengan tingkat pendapatan para pedagang kecil.

\section{Uji Regresi Linier Sederhana}

Tabel 1.4

Tabel Uji Regresi Linier Sederhana

Coefficients $^{\mathrm{a}}$

\begin{tabular}{|c|c|c|c|c|c|}
\hline \multirow[b]{2}{*}{ Model } & \multicolumn{2}{|c|}{ Unstandardized Coefficients } & \multirow{2}{*}{$\begin{array}{l}\text { Standardized } \\
\text { Coefficients }\end{array}$} & \multirow[b]{2}{*}{$\mathrm{T}$} & \multirow[b]{2}{*}{ Sig. } \\
\hline & $\mathrm{B}$ & Std. Error & & & \\
\hline 1 (Constant) & 11,955 & 1,945 & & 6,146 &, 000 \\
\hline Kredit & .334 & 106 & 390 & 3,139 & .003 \\
\hline
\end{tabular}

Sumber : Lampiran 9

Dari hasil pengujian diatas dapat kita lihat angka konstan yang di dapat adalah 11,995 ini merupakan angka yang mempunyai arti bahwa jika tidak ada kredit yang diterima oleh para padagang kecil maka pendapatan ( $\mathrm{Y}$ ) yang di dapat adalah 11,955. Sedangkan angka koefisien regresi nilainya sebesar 0,334 hal tersebut berarti bahwa setiap penambahan $1 \%$ kredit yang diterima para pedagang $(\mathrm{X})$ maka pendapatan yang diterima oleh para pedagang kecil ( Y ) sebesar 0,334. Persamaan regresi linier sederhananya dapat ditulis sebagai berikut $: \mathbf{Y}=\mathbf{a}+\mathbf{b x} \longrightarrow \mathbf{Y}=11,995+\mathbf{0 , 3 3 4 x}$ sehingga dapat disimpulkan bahwa pemberian kredit modal kerja yang diterima para pedagang kecil bernilai positif terhadap tingkat pendapatannya.

\section{Uji Korelasi ( Uji T )}

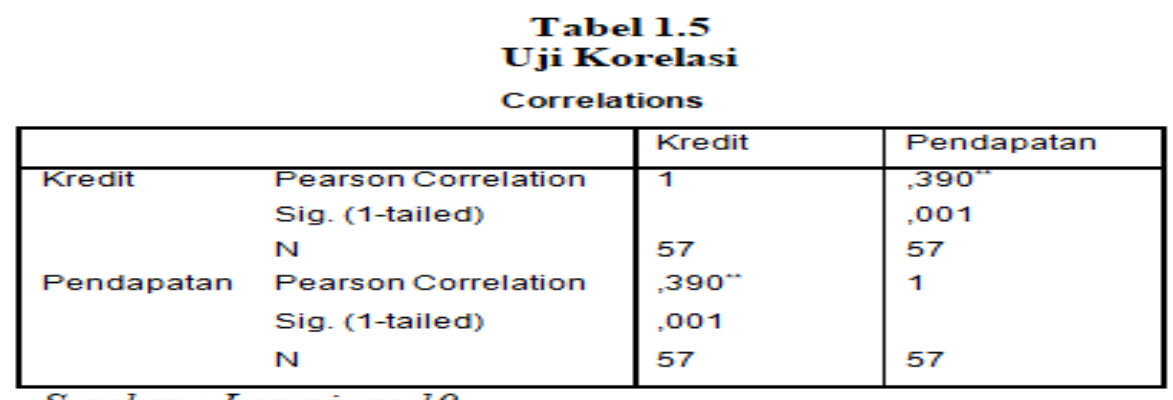

Sumber: Lampiran 10 
Jurnal Kompetitif : Media Informasi Ekonomi Pembangunan, Manajemen dan Akuntansi Vol. 6 No. 2, September 2020

Dari hasil uji korelasi diatas didapatkan nilai pearson correlation sebesar 0,390 dengan taraf signifasi sebesar $1 \%$ ini berarti pemberian kredit modal kerja mempunyai pengaruh yang cukup signifikan terhadap pendapatan yang diperoleh para pedagang kecil hal ini berarti semakin besar kredit yang diterima maka akan semakin besar pula pendapatan yang akan diperoleh. Sementara Sig.(1-tiled) diperoleh hasil 0,001 lebih kecil dari 0,005 ini membuktikan variabel kredit yang diberikan dengan variabel tingkat pendapatan para pedagang kecil menunjukan hasil yang signifikan positif. Hasil t hitung sebesar 3,139, jika di dibandingkan dengan t tabel pada taraf signifasi sebesar 0,005 dan $\mathrm{N}=57$ diperoleh hasil $\mathrm{r}$ tabel $=1,67203$ maka didapat hasil $\mathrm{t}$ hitung $>$ dari $\mathrm{t}$ tabel ini membuktikan bahwa pemberian kredit modal kerja terhadap pendapatan pedagang kecil mempunyai hubungan yang signifikan.

\section{Koefisien Determinasi ( R Square )}

Tabel 1.6

Koefisien Determinasi

\begin{tabular}{|c|c|c|c|c|}
\hline Model & $\mathrm{R}$ & R Square & $\begin{array}{l}\text { Adjusted } R \\
\text { Square }\end{array}$ & $\begin{array}{l}\text { Std. Error of the } \\
\text { Estimate }\end{array}$ \\
\hline 1 &, $390^{\mathrm{a}}$ & ,152 & ,137 & 1,35986 \\
\hline
\end{tabular}

Sumber : Lampiran 11

Dari hasil olah data diatas nilai koefisien determinasi atau R Square adalah 0,152 atau $15,2 \%$ hal ini berarti pengaruh variabel X ( Kredit yang diberikan ) berpengaruh terhadap variabel Y ( Pendapatan Para Pedagang Kecil) sebesar 15,2\% sendangkan sisanya $(100 \%-15,2 \%=84,8 \%)$ dipengaruhi oleh faktor lain yang tidak diteliti dalam penelitian ini.

Setelah peneliti melakukan pengujian terhadap penelitian ini didapatkan hasil bahwa pengaruh pemberian kredit modal kerja berpengaruh signifikan terhadap tingkat pendapatan pedagang kecil pada kantor PD. BPR NTB Lombok BaratCabang Gunungsari, jadi hipotesis yang menyatakan bahwa terdapat pengaruh pemberian kredit modal kerja 
Jurnal Kompetitif : Media Informasi Ekonomi Pembangunan, Manajemen dan Akuntansi Vol. 6 No. 2, September 2020

terhadap peningkatan pedagang kecil pada Kantor PD.BPR NTB Lombok Barat Cabang Gunungsari secara parsial diterima.

\section{PENUTUP}

\section{Kesimpulan}

Dari hasil analisis data pada pembahasan diatas penulis dapat menarik kesimpulan sebagai berikut :

a. Dalam penelitian terdapat dua variabel yang akan diteliti yaitu varibael bebas kredit modal kerja dan variabel terikat yaitu pendapatan pedagang kecil. Hasil dari penelitian yang dilakukan pada korelasi (uji t) membuktikan bahwa kredit modal kerja yang diberikan oleh PD. BPR NTB Lobar Cabang Gunungsari terdapat pengaruh yang signifikan positif terhadap pendapatan pedagang kecil. Hasil t-hitung $=3,139>\mathrm{t}$-tabel $=1,67203$ pada taraf signifasi sebesar 0,005 dan $\mathrm{N}=57$.

b. Berdasarkan hasil uji koefisien determinasi diperoleh nilai $\mathrm{R}$ Square $=15,2 \%$ yang artinya hanya $15,2 \%$ dari pemberian kredit modal kerja yang memepngaruhi tingkat pendapatan pedagang kecil pada PD. BPR NTB Lobar Cabang Gunungsari sedangkan sisanya $84,8 \%$ dipengaruhi oleh faktor lain yang tidak diteliti dalam penelitian ini.

\section{Saran}

1. Pemberian kredit modal kerja oleh perbankan hendaknya dipergunakan untuk memenuhi kebutuhan modal usaha bukan untuk kebutuhan konsumtif sehingga usaha dan pendapatan berkembang serta pengajuan pinjaman kredit harus sesuai dengan kemampuan bayarnya agar dikemudian hari tidak terjadi kredit macet.

2. Pihak BPR hendaknya melakukan pengawasan terhadap penggunaan kredit tersebut agar kredit yang dicairkan penggunaanya tepat sasaran yaitu menunjang permodalan para pedagang. Selain itu perlu diadakan kegiatan pemasaran, sosialisasi, penyediaan klinik konsultasi usaha dan pelatihan-pelatihan bagi para pedagang usaha kecil dalam rangka meningkatkan pengetahuan pelaku usaha dalam mengelola usahanya dan meningkatkan pengetahuan masyarakat tentang keberadaan BPR di pelosok. 
Jurnal Kompetitif : Media Informasi Ekonomi Pembangunan, Manajemen dan Akuntansi

Vol. 6 No. 2, September 2020

\section{DAFTAR PUSTAKA}

Azwar, Saifuddin. 1999. Metode Penelitian. Pustaka Pelajar Yogyakarta

Brosur Bank Perkreditan Rakyat. 2010. ”Model Bisnis Bank Perkreditan Rakyat"

Desna Putri Pamulasari. 2013 degan judul "Pengaruh Pemberian Kredit Modal Kerja terhadap Peningkatan Pendapatan Usaha Mikro Kecil dan Menengah pada Kopersari Wijaya di Kelurahan Wirun Kecamatan Mojolaban”.

Gilarso T. (2004).Pengantar Ilmu Ekonomi Makro. Yogyakarta : Karnisus.

Jusup Al.Haryono. 1997. Dasar-Dasar Akuntansi. Sekolah Tinggi Ilmu Ekonomi YKPNYogyakarta,

Linda Kumalasari. 2013. yang berjudul "Pengaruh Pengambilan Kredit di Koperasi Jasa Keuangan Syariah (KJKS) terhadap pendapatan pedagang kecil di pasar Tanjung Kabupaten Jember tahun 2012/2013”,

Republik Indonesia.Undang-undang Perbankan Pasal 13 No.10 Tahun 1998 Tugas dan Kegiatan Bank Perkreditan Rakyat

Riyanto, Bambang. 2013. Dasar-Dasar Pembelanjaan Perusahaan. Edisi Keempat. BPFE-Yogyakarta. Yogyakarta.

Setiawan,Santy. 2012. Statistika II.. Bandung: ANDI

Sobri. 1987. Pengantar Ekonomi Makro. Edisi Revisi Cetakan Kedua. Yogyakarta: BPFE. UI.

Soekartawi. 1994. Prinsip Dasar Ekonomi Pertanian: Teori dan Aplikasi. Rajawali Press. Jakarta.

Sukirno,Sadono, 2006, Ekonomi Pembangunan, Jakarta:Kencana

Sugiyono. 2011. Statistika untuk Penelitian. Bandung: Alfabeta.

Tjoekam, Moehamad. Perkreditan Bisnis Inti Bank Komersil (Jakarta: Gramedia

Pustaka Utama, 1999.

Todaro, Michael P., 1998, Pembangunan Ekonomi Di Dunia Ketiga, Edisi Keenam, Jakarta: Erlangga.

Winardi., 1986, Asas-asas Manajemen, Bandung: Alumni. 